Scientia Marina 70(4)

December 2006, 607-619, Barcelona (Spain)

ISSN: 0214-8358

\title{
Holocene neoglacial events in the Bransfield Strait (Antarctica). Palaeocenographic and palaeoclimatic significance
}

\author{
MARÍA ÁNGELES BÁRCENA ${ }^{1}$, JOAN FABRÉS ${ }^{2}$, ENRIQUE ISLA ${ }^{3}$, JOSÉ ABEL FLORES ${ }^{1}$, \\ FRANCISCO JAVIER SIERRO ${ }^{1}$, MIQUEL CANALS ${ }^{1}$ and ALBERT PALANQUES ${ }^{3}$ \\ ${ }^{1}$ Dpto. Geologia, Paleontologia, Fac. Ciencias, Universidad de Salamanca, 37008 Salamanca, Spain. \\ E-mail:mbarcena@usal.es \\ ${ }^{2}$ GRC Geociencies Marines, Dpt. Geologia Dinamica, Geof. i P. Universitat de Barcelona, Campus de Pedralbes, \\ 08071 Barcelona, Spain. \\ ${ }^{3}$ Instituto Ciencias del Mar (CSIC). Passeig Maritim de la Barceloneta 37-49. 08003 Barcelona, Spain.
}

\begin{abstract}
SUMMARY: Geochemical analysis, micropalaeontological analysis and radiometric dating techniques were performed on four gravity cores, G-1, G-2, A-3 and A-6, recovered during the BIO Hesperides expeditions GEBRA-93 and FRUELA-96 from the Bransfield Strait (Antarctica). Moreover, in order to improve the sedimentation rate control we tentatively relate abundance variations in the sea-ice taxa group (SITG) to air temperature estimations based on Deuterium contents in Vostok ice-core. The results of diatom analyses were related to the sequence of neoglacial events that have occurred over the last three millennia. For these periods, a restricted communication between the Weddell, Bransfield and Bellingshausen seas has been proposed. The abundance patterns of diatom valves, resting spores (RS) of the diatom Chaetoceros and opal content agree with the high productivity values previously reported for the area. The significant reduction Chaetoceros RS towards the present is interpreted as a reduction in surface productivity. Trend differences between Chaetoceros RS and TOC contents are explained in terms of organic matter preservation. Diatom communities from the Bransfield Strait did not play an important role in the global $\mathrm{CO}_{2}$ cycle during cold periods. Bio- and geochemical changes have overprinted high frequency cyclicity at about $200-300 \mathrm{yr}$, which might be related to the $200-\mathrm{yr}$ solar cycle.
\end{abstract}

Keywords: diatoms, geochemistry, neoglacial events, palaeoceanography,

palaeocliomatology, Holocene, Bransfield Strait, Antarctica.

RESUMEN: Eventos NeOglaciales del Holoceno en el estrecho de Bransfield (Antártica). Significado PaleoceaNOGRÁFICO Y PLAEOCLIMÁTICO. - Se han realizado análisis geoquímicos y micropaleontológicos, así como técnicas de datación radiométricas sobre cuatro testigos de gravedad (G-1, G2, A-3 y A-6) recuperados durante las campañas del BIO Hespérides Gebra-93 y Fruela-96 en el Estrecho de Bransfield (Antártida). Se han correlacionado las estimaciones de temperatura del aire, derivadas del contenido en Deuterio en el testigo de hielo Vostok, con la abundancia del grupo de taxones de mar helado (SITG). Los resultados obtenidos del análisis de diatomeas han sido relacionados con la secuencia de eventos neoglaciales que tuvieron lugar durante los últimos 3000 años. Se propone una restricción en la comunicación entre el Mar de Weddel, Estrecho de Bransfield y Mar de Bellingshausen durante los episodios neoglaciales. Los patrones de abundancia de valvas de diatomeas, esporas (RS) de Chaetoceros y el contenido en ópalo biogénico indican valores altos en productividad, previamente descritos para el área. La progresiva reducción en Chaetoceros (RS) hacia techo se ha interpretado como reducción en la productividad superficial. Las diferencias entre la abundancia de Chaetoceros (RS) y el contenido en carbono orgánico (TOC) puede deberse a diferencias en la preservación de la materia orgánica. Por otro lado, los datos analizados indican que las comunidades de diatomeas del estrecho de Bransfield no jugaron un papel determinante en el ciclo global del $\mathrm{CO}_{2}$ durante los episodios fríos. Los cambios bio-geoquímicos están marcados por una ciclicidad de alta frecuencia de 200-300 años que podría estar relacionada con el ciclo solar de 200 años.

Palabras clave: diatomeas, geoquímica, eventos neoglaciales, paleoceanografía, paleoclimatología, Holoceno, Estrecho de Bransfield, Antártida. 


\section{INTRODUCTION}

The Holocene has been a period of rapid climate change in which climate records have been obtained from both hemispheres (Domack and Mayewski, 1999). The interhemispheric occurrence of neoglacial events points to a primary astronomical reason forcing climatic change, involving tele-connections between the cryosphere and atmosphere systems. Several studies have proposed a solar activity forcing with a 200-yr rhythm based on reductions in sunspot activity. Evidence for these events, among others, was also found in Antarctic marine sediments by Leventer et al. (1996) and Bárcena et al. (1998, 2002), who observed that the climatic system along the Antarctic Peninsula oscillates with the solar activity rhythm.

The Antarctic Peninsula area, especially the Bransfield Strait Basin, is highly sensitive to finescale climatic and oceanographic changes, as well as to changes in local tidewater glaciers. Previous studies have shown that the general trend for the last three thousand years has been a reduction in primary productivity towards the present (Bárcena et al., 1998, 2002; Domack, 2001). Overprinted on this trend is a high-frequency oscillation in diatom abundance, which correlates with an approximately 250 year cyclicity, recognised in magnetic susceptibility, organic carbon, nitrogen and siliceous microfossil data (Leventer et al., 1996; Bárcena et al., 1998, 2002; Domack, 2001). These changes in primary productivity over time are mainly controlled by seaice conditions and surface water stability and stratification. Since over the years vertical fluxes are restricted to a short period, i.e. the austral summer (Wefer et al., 1988), palaeoclimatic evolution may help to study and better understand the biogenic cycles involved.

The present work addresses the sedimentary record during the last 3000 years and its relationship with palaeoceanographic evolution, such as changes in primary production, fluctuations in sea-ice cover, and surface hydrodynamics. This evolution was studied on the basis of the diatom assemblages preserved in the sedimentary column and the biogenic silica and organic carbon stored in the sediments. The relatively high accumulation rates found in this area afford sufficient resolution to study the effects of climatic changes over the last three millennia. Study of the changes that took place in the past may help to improve knowledge of the carbon cycle and to evaluate the possible causes of present climatic and oceanographic changes.

\section{PHYSICAL ENVIRONMENT}

The Bransfield Strait is a semi-enclosed basin limited by the Antarctic Peninsula to the south and by the South Shetland Islands to the north (Fig. 1). Gordon and Nowlin (1978) discussed the hydrodynamics in the Bransfield Basin in depth. In general, surface waters in the Bransfield Basin have two primary sources: the Bellingshausen Sea to the west and south brings warm and relatively fresh waters (Transitional Bellingshausen Water, TBW), and the Weddell Sea to the east brings a large amount of cold and dense water (Transitional Weddell Water, TWW) (Fig. 1). The two currents meet in the vicinity of Trinity Island, where they form a front of biological significance (Amos, 1987). The Circumpolar Deep Water (CDW) from the Drake Passage enters the Bransfield Basin through the south-western end of the Strait. This entry is partially prevented by the presence of shallow sills that form the western and northern boundaries of the basin.

The sediments accumulated in the Bransfield Basin have been described as silica-rich muds and silty clay sediments that are made up of three components: biosiliceous material, diatoms and radiolarians; a terrigenous component, quartz silt; and volcanic ash (Ercilla et al., 1997, Fabrés et al., 2000). Most of the terrigenous fine particles accumulated in the Bransfield Basin derive from subglacial and fluvial discharge from glaciers (Fabrés et al., 2000). The glaciogenic particles (IRD) as well as the volcanic dust eroded or coming directly from volcanic eruptions also reach the basin floor (Fabrés et al., 2000). Moreover, planktonic productivity is the second major source of hemipelagic particles. The Bransfield Strait is a very high productivity area, the reported values of primary production there ranging from $330 \pm 43$ to $2673 \pm 1754 \mathrm{mg} \mathrm{C} \mathrm{m}^{-2}$ day $^{-1}$ (Bodungen et al., 1986; Basterrechea and Aristegui, 1999). This results in high sedimentation rates for the basin floor sediments (Abelmann and Gersonde, 1991). Comparison of the sedimentation rates and estimations of surface production indicate that the silica accumulation rate in the Bransfield Basin accounts for approximately half of the surface production rate. Alterations of the assemblages of siliceous organisms during vertical transport through 


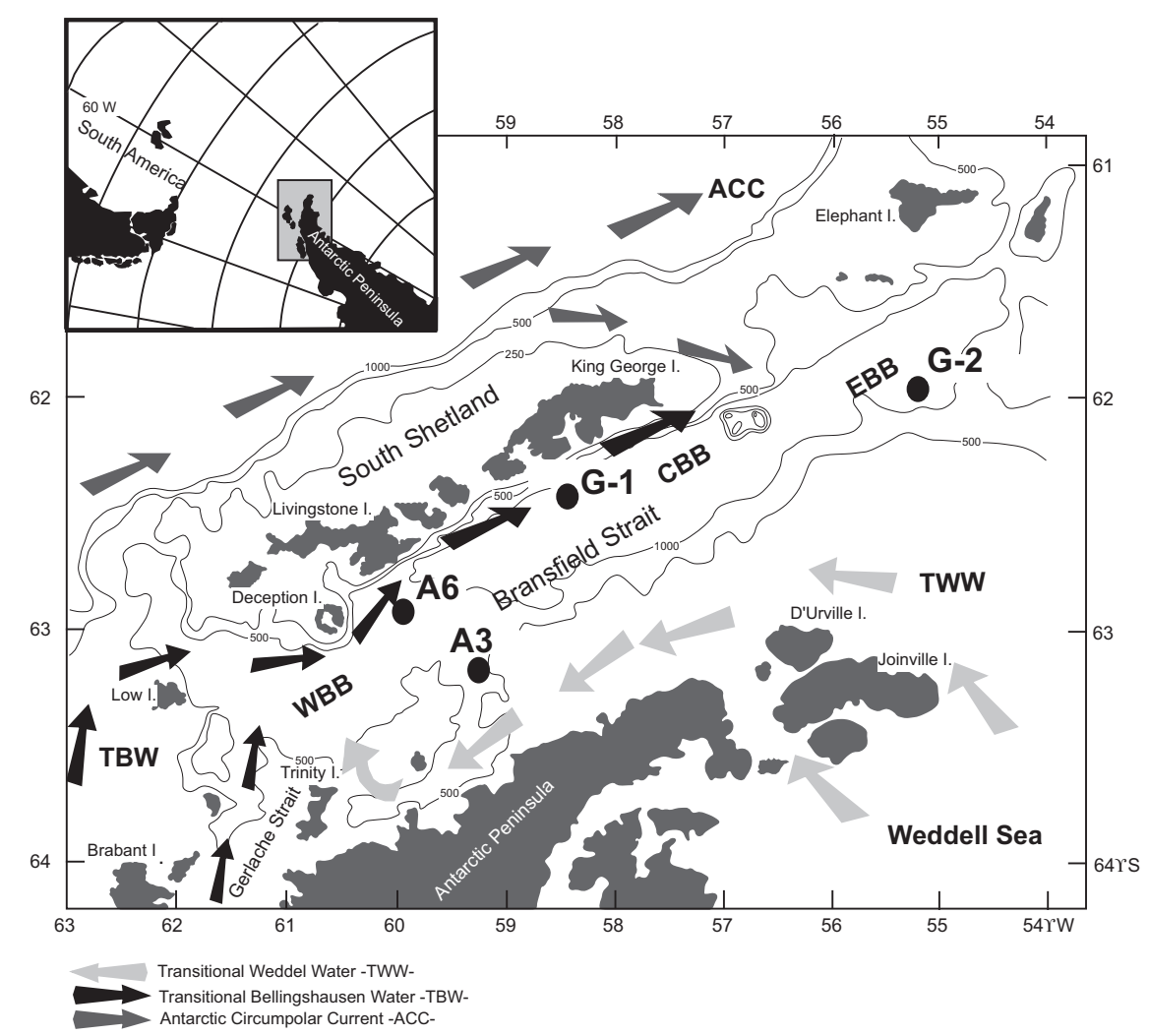

FIG. 1. - Schematic surface circulation pattern in Bransfield Strait and core locations of G-1, G-2, A-3 and A-6.

the water column are due to mechanical breakdown by grading zooplankton and to dissolution (Gersonde and Wefer, 1987). Another factor responsible for the composition of the biosiliceous signal in the sediment record is the input of laterally transported material (Abelmann and Gersonde, 1991).

The sea-ice distribution in the Bransfield Basin has a strong and complex seasonal pattern. The annual sea-ice coverage shows a maximum winter extent of $57^{\circ} \mathrm{S}$ off the Antarctic Peninsula, while in the summer it is completely ice-free (N.O.C., 1985). Surface productivity, and therefore export production of biogenic particles on the sediments is restricted to ice-free periods, when it reaches one of the highest rates of the entire western part of the Atlantic sector of the Southern Ocean. Data gathered from four-season time-series traps have indicated that over $95 \%$ of the annual flux at shallow and mid-depths occurs during December and January; therefore maxima in particle flux occur in open water conditions, whereas during sea-ice coverage the vertical flux of siliceous organisms from the surface waters is extremely low (Wefer et al., 1988; Abelmann and Gersonde, 1991; Palanques et al., 2002).

\section{MATERIALS AND METHODS}

Gravity cores G-1 and G-2 were recovered during the RV Hesperides cruise GEBRA-93 in the eastern Bransfield Basin. Position, length and water depth are detailed in Table 1 and Figure 1. Both cores are detailed as described in Fabrés et al. (2000). Gravity cores A-3 and A-6 were recovered during the RV Hesperides cruise FRUELA-96 in the western Bransfield Basin. Position, water depth and length are detailed in Table 1 and Figure 1. Samples were taken every $5 \mathrm{~cm}$ for Total Organic Carbon (TOC) and opal analyses. For micropalaeontological studies, cores G-1, G-2 and A-3 were sampled every $10 \mathrm{~cm}$ and every $5 \mathrm{~cm}$ for A-6.

Total Organic Carbon for cores G-1 and G-2 was determined in a Fisons model NA 1500 elemental analyser using decalcified samples. The TOC for A3 and A-6 was determined in a LECO CN-2000 resistance furnace at $1050^{\circ} \mathrm{C}$.

A modified Mortlock and Froelich (1989) extraction procedure was used to analyse the biogenic silica content. The spectrometer used for G-1 and G-2 was a Polyscam ${ }^{\mathrm{TM}}$ G1 E. Silica content in cores A-3 and A- 6 was measured by molibdate-bluespectrom- 
etry. The silicon abundances obtained were converted to opal abundances using the conversion factor of 2.4 proposed by Mortlock and Froelich (1989).

Cleaning of the sediment samples and preparation of permanent mounts for light microscopy were accomplished according to the randomly distributed microfossils method outlined in Bárcena and Abrantes (1998). For the counting routines, a Leica DMLB microscope at $1000 \mathrm{X}$ magnification was used. In general, more than 600 valves per sample were considered using the method of Schrader and Gersonde (1978). The preservation status of the fossil assemblage was estimated by visual examination.

\section{CHRONOLOGICAL ASSESSMENT}

Bárcena et al. $(1998,2002)$ presented a detailed explanation of the different radiometric dating techniques used to determine the precise age and sedimentation rates of the cores investigated. In general, for cores G-1 and G-2 ages were determined by a combination of three different radiometric techniques: ${ }^{230} \mathrm{Tho} /{ }^{234} \mathrm{U}$, AMS ${ }^{14} \mathrm{C}$ chronology and ${ }^{210} \mathrm{~Pb}$ excess by $\gamma$-spectrometry. Cores A-3 and A- 6 were dated by AMS ${ }^{14} \mathrm{C}$ chronology and ${ }^{210} \mathrm{~Pb}$ excess $(\gamma$ spectrometry).

The AMS ${ }^{14} \mathrm{C}$ technique, carried out on TOC, was the most appropriate for the type of sediment in the cores studied. Three stratigraphic levels were examined in each core (Table 1). This yielded a ${ }^{14} \mathrm{C}$ age older than expected (Table 1). Despite this, the ages display a clear down-core pattern, indicating a linear and high sedimentation rate Bárcena et al. $(1998,2002)$ in agreement with the accumulation rates given in the literature. In this area radiocarbon dating yields anomalous old ages caused by two main effects: the large and regionally variable reservoir effect, which results in an age delay of 12001400 years, and the input of older eroded sediment that was re-deposited as a result of lateral transport, current winnowing, and mass-wasting processes (Stuiver et al., 1981 and Harden et al., 1992). Moreover, ice-rafting of fine particles from icebergs could also contribute to this effect.

Determination of ${ }^{210} \mathrm{~Pb}$ anomalies allowed us to interpret the core top of G-1 as present-day sediments, and the core top ages for cores A-1 and A-3

TABLE 1. - Core location, core length, and ${ }^{14} \mathrm{C}$ conventional ages for each core analysed. Tie points for correlation between SITG maxima and deuterium content in Vostok ice-core as well as calendar kiloyears.

\begin{tabular}{|c|c|c|c|c|c|c|c|c|}
\hline Core & $\begin{array}{l}\text { Latitude } \\
\quad(\mathrm{S})\end{array}$ & $\begin{array}{l}\text { Longitude } \\
\text { (W) }\end{array}$ & $\begin{array}{c}\text { water } \\
\text { depth (m) }\end{array}$ & $\begin{array}{l}\text { core length } \\
\quad(\mathrm{cm})\end{array}$ & $\begin{array}{l}\text { Section } \\
(\mathrm{cm})\end{array}$ & $\begin{array}{c}{ }^{14} \mathrm{C} \text { Conventional } \\
\text { age }\end{array}$ & $\begin{array}{l}\text { Pointers } \\
\text { (depth } \mathrm{cm})\end{array}$ & $\begin{array}{l}\text { Calendar } \\
\text { kiloyears }\end{array}$ \\
\hline G-1 & $62^{\circ} 35.36^{\prime}$ & $58^{\circ} 32.53^{\prime}$ & 1652 & 251 & $\begin{array}{l}28 \\
135 \\
240\end{array}$ & $\begin{array}{l}2585 \pm 39 \\
3959 \pm 49 \\
4646 \pm 37\end{array}$ & $\begin{array}{c}1 \\
41 \\
71 \\
101 \\
121 \\
211 \\
251\end{array}$ & $\begin{array}{l}0,072 \\
0,191 \\
0,280 \\
0,451 \\
0,640 \\
1,135 \\
1,664\end{array}$ \\
\hline G-2 & $61^{\circ} 56.56^{\prime}$ & $55^{\circ} 10.21^{\prime}$ & 1106 & 454 & $\begin{array}{l}25 \\
225 \\
440\end{array}$ & $\begin{array}{l}2796 \pm 34 \\
3916 \pm 36 \\
5385 \pm 39\end{array}$ & $\begin{array}{c}10 \\
50 \\
85 \\
130 \\
170 \\
250 \\
300 \\
420 \\
40 \\
70\end{array}$ & $\begin{array}{c}0,235 \\
0,425 \\
0,64 \\
1,102 \\
1,375 \\
1,664 \\
2,200 \\
2,767 \\
0,170 \\
0,280\end{array}$ \\
\hline A-3 & $63^{\circ} 10.06^{\prime}$ & $59^{\circ} 18.13^{\prime}$ & 810 & 437 & $\begin{array}{c}0 \\
300 \\
437\end{array}$ & $\begin{array}{l}3960 \pm 50 \\
5090 \pm 50 \\
5990 \pm 50\end{array}$ & $\begin{array}{l}120 \\
190 \\
250 \\
300 \\
430\end{array}$ & $\begin{array}{l}0,640 \\
0,972 \\
1,069 \\
1,202 \\
1,664\end{array}$ \\
\hline A-6 & $62^{\circ} 54.71^{\prime}$ & $59^{\circ} 58.21^{\prime}$ & 1066 & 134 & $\begin{array}{c}0 \\
134\end{array}$ & $\begin{array}{l}3410 \pm 50 \\
5070 \pm 50\end{array}$ & $\begin{array}{c}0 \\
20 \\
60 \\
80 \\
120\end{array}$ & $\begin{array}{l}0,149 \\
0,280 \\
0,640 \\
0,877 \\
1,554\end{array}$ \\
\hline
\end{tabular}




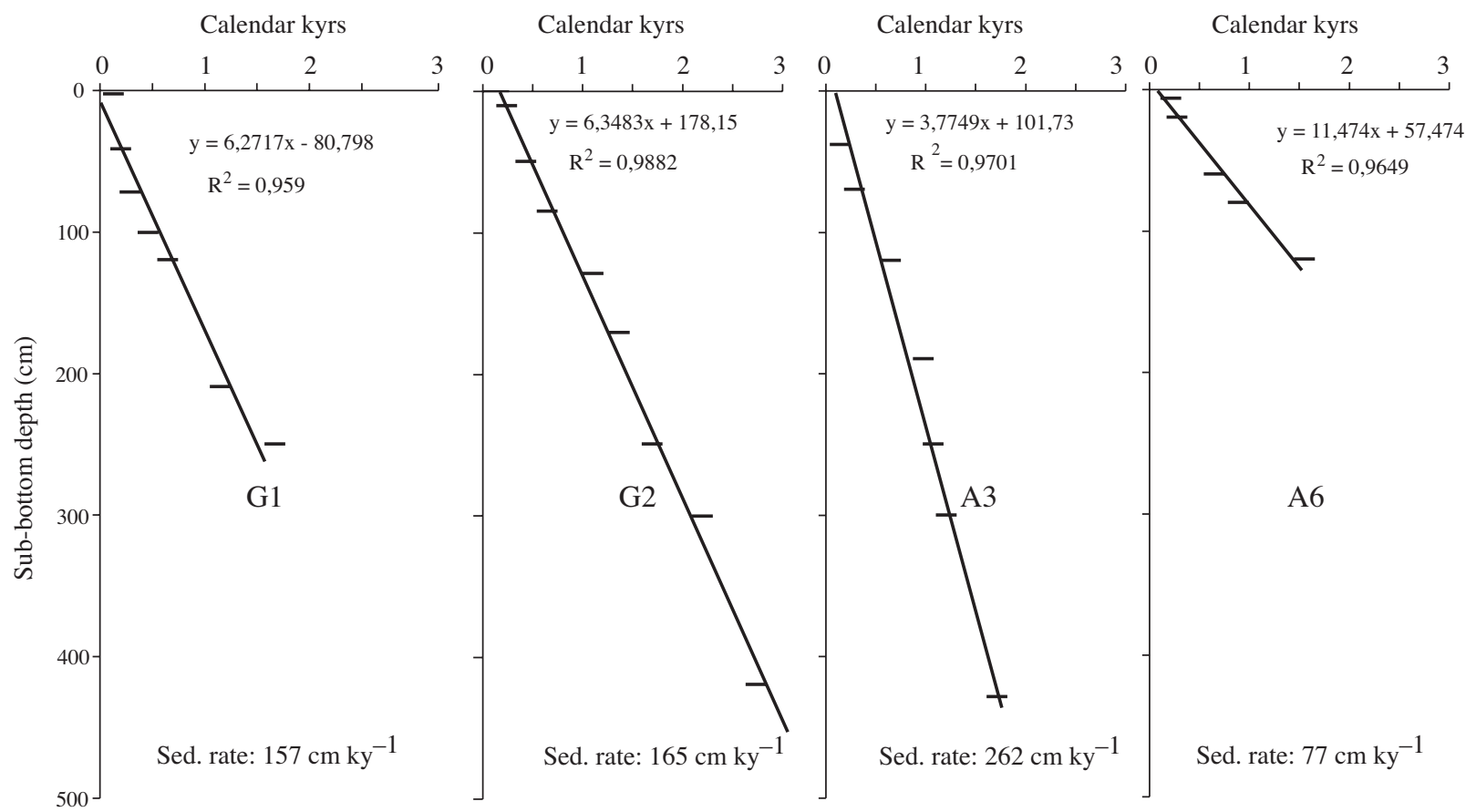

FIG. 2. - Age-depth curve for cores G-1, G-2, A-3 and A-6. For age model routines the Analyses series Program (Paillard, 1996) was used. See also Table 1.

was estimated to be not older than $100 \pm 15$ years B.P. The chronological criteria used in this work to determine the age of the sediments recorded in the gravity cores studied here have been explained previously in Bárcena et al. (1998, 2000).

Taking into account that both the regional reservoir effect and local processes have a strong influence on stratigraphic control, fine-scale differences in sedimentation rates cannot be determined, and it is necessary to know the limitations in radiocarbon dating, which may undergo some variations. Assuming this, we tentatively link the variations in the organic components of the sediments as well as the siliceous microfossil abundance patterns of G-1, G-2, A-3 and A-6 to climatic changes.

Based on the well-documented air composition recorded in Antarctic ice cores, six cold episodes have been recognised in the last three millennia (Indermühle et al., 1999, Petit et al., 2000), but they are also well documented on marine sediments from the Antarctic Peninsula region (Leventer et al., 1996 and Bárcena et al., 1998, 2002). Therefore, in order to improve the sedimentation rate control in all cores we tentatively relate abundance variations in the sea-ice taxa group (SITG) directly related to climatic changes and sea-ice distribution, as widely discussed by Armand et al. (2005), to air temperature estimations based on Deuterium contents in Vostok ice-core (Petit et al., 2000). Tie points are show in
Table 1. The use of age model routines in the Analyses Series Program (Paillard, 1996) allowed us to establish a good correlation between all cores addressed in this study. The sedimentation rates estimated for the cores do not vary significantly from those based on AMS ${ }^{14} \mathrm{C}$ data. Thus, we have obtained linear sedimentations rates of $157 \mathrm{~cm} \mathrm{ky}^{-1}$ for G-1, $165 \mathrm{~cm} \mathrm{ky}^{-1}$ for G-2, $262 \mathrm{~cm} \mathrm{ky}^{-1}$ for A-3 and $77 \mathrm{~cm} \mathrm{ky}^{-1}$ for A6 (Fig. 2).

\section{RESULTS}

\section{Diatoms}

High numbers of diatom valves per gram of dry sediment were observed in both cores, ranging from $2 \times 10^{7}$ to $14.7 \times 10^{8}$ (Fig. 3 ). The diatoms were in general well preserved. The diatom assemblage was dominated by Chaetoceros resting spores (RS) (65-90\% of the total). The SITG includes species such as Fragilariopsis curta, F. cylindrus and F. vanheurckii. This group was frequent, with abundances of up to $11.8 \%$ of the total. Thalassiosira antarctica group was another component of the assemblage. This group has been related to oceanic conditions from the Weddell and Scotia Seas (Abelmann and Gersonde, 1991). F. kerguelensis is also considered to be an open water species since it 
612 • M.A. BÁRCENA et al.
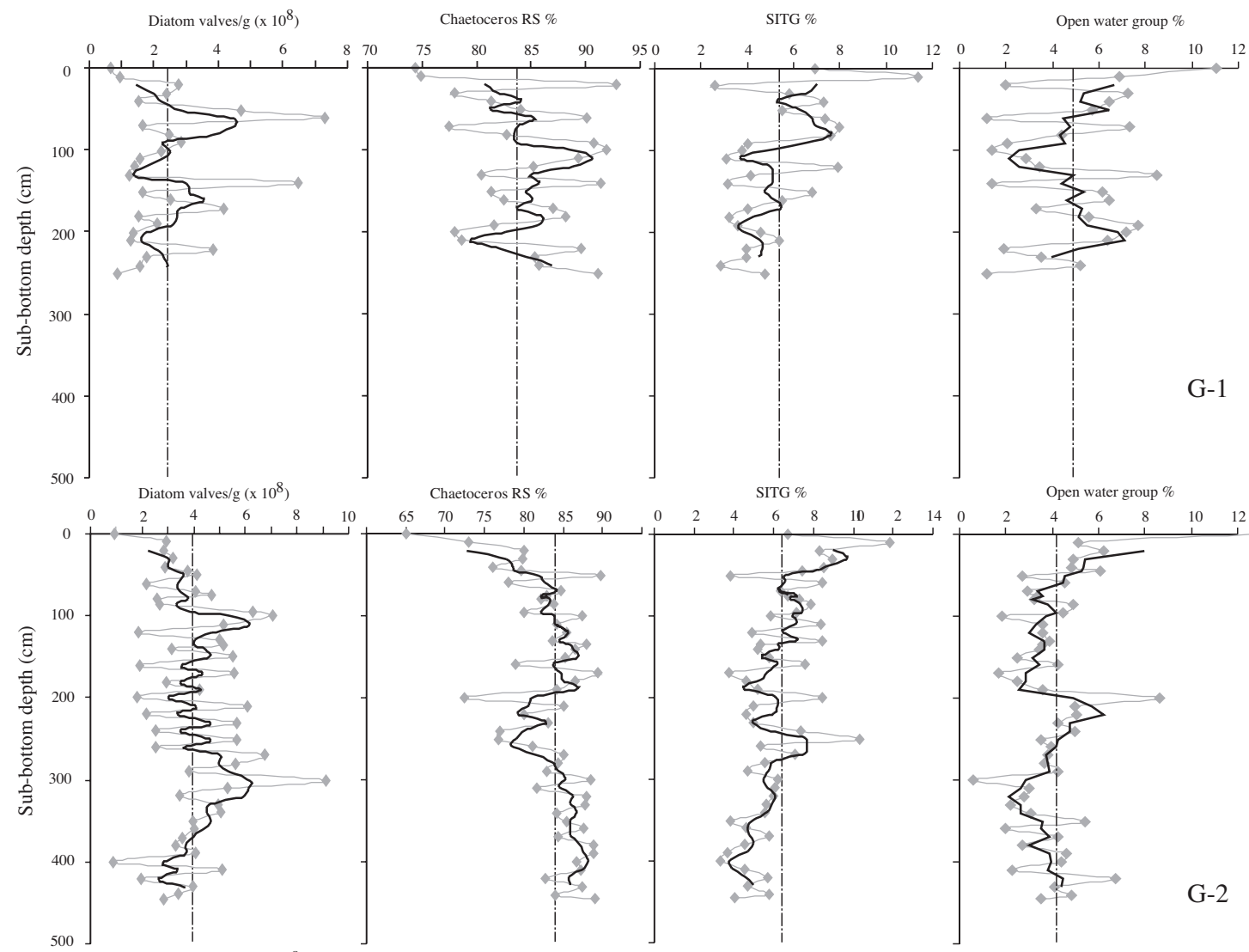

$4 \quad 6 \quad 8$
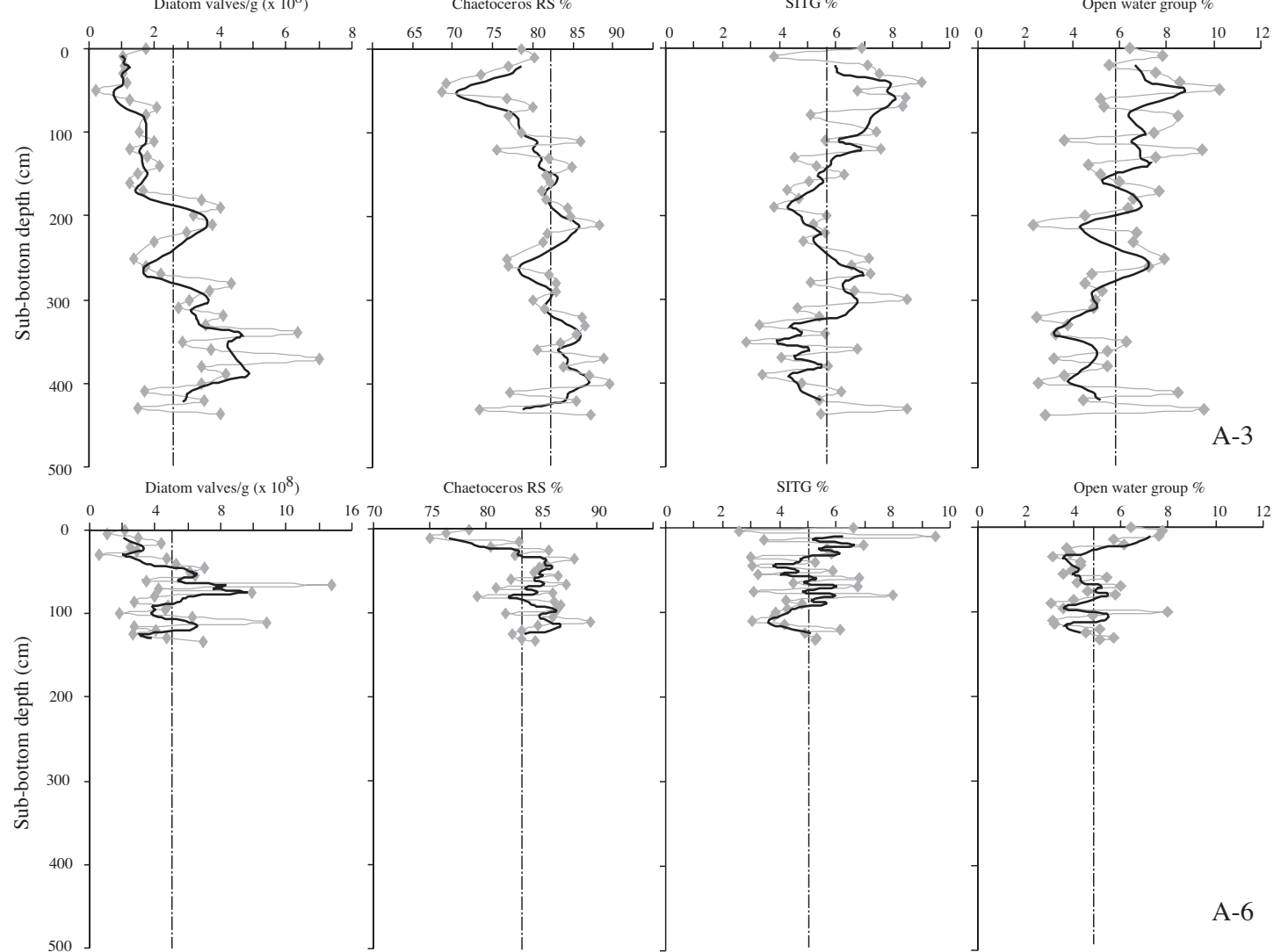

FIG. 3. - Diatom abundance expressed as valves/g of dry sediment, relative abundance (\% of assemblage) of Chaetoceros RS, sea-ice taxa group (SITG) and open water group (OWG) in cores G-1, G-2, A-3 and A-6. Thicker line indicates a three-point smoothing. 
is characteristic of the Antarctic Circumpolar Current (ACC), is common in surface sediments of the Southern Ocean, and dominates the sediment trap assemblages and surface sediments of the Drake Passage (Zielinski and Gersonde, 1997). Owing to the ecological living preferences of the $T$. antarctica group and F. kerguelensis in open water areas surrounding the Bransfield Strait, we believe that both species could be considered as an open water group (OWG) of outside open water conditions. The species distributions in all cores and relative abundances were in agreement with the values compiled from the literature for the Bransfield Strait area (Gersonde and Wefer, 1987; Abelmann and Gersonde, 1991; Bárcena et al., 1998, 2002; Varela et al., 2002).

In general, the total abundance of diatom valves/g of dry sediment tended to decrease towards the top (Fig. 3). The large numbers of Chaetoceros $\mathrm{RS}$ in the sediments masks the signal of the entire assemblage. The abundance pattern of Chaetoceros RS follows a similar trend to that observed for total diatom valve abundance (Fig. 3). On the other hand, the abundance pattern of the SITG follows the opposite behaviour to that observed for Chaetoceros RS. Maximum values in Chaetoceros RS correspond to minima in SITG (Fig. 3).

In G-2, SITG tend to increase from the base to the top, reaching their maximum value at a $20 \mathrm{~cm}$ core depth. More detailed down-core analysis of the abundance of SITG showed that this group had two minima. The first was observed from the base to the $340 \mathrm{~cm}$ sample, while the second one lay between samples 240 and $140 \mathrm{~cm}$, where higher values than the former minimum were obtained (Fig. 3). An increased abundance pattern from the base to the top was also observed in G-1 (Fig. 3). The diatom patterns of cores A-3 and A- 6 were remarkably similar, given the missing core top for A- 6 as well as differences in sedimentation rates.

The open water group (OWG) showed an inverse relation to the Chaetoceros RS abundance curve, in core G-2. The group had a quasi-periodic down-core distribution. In contrast, the OWG and the SITG seemed to be inversely correlated in the lower part of the core, from the base to $190 \mathrm{~cm}$, while both curves seemed to co-vary from this core depth to the top (Fig. 3). In core G-1, the OWG had two maxima in abundance at approximately 205180 and $80 \mathrm{~cm}$ core depth, respectively. The general tendency of the OWG, compared to that of the
SITG, was also similar in the upper part of G-2 (Fig. 3 ). Therefore, the two curves were not in phase, SITG occuring earlier than OWG. A similar pattern was observed in cores A3 and A6. The OWG showed an inverse relation to the Chaetoceros RS abundance curve, and was similar to but not in phase with that of the SITG (Fig. 3).

\section{Total organic carbon and biogenic opal}

The mean TOC content was quite high: $1.19 \%$ for G-1; $1.15 \%$ for G-2; $1.03 \%$ for A-3, and $0.47 \%$ for A-6 (Fig. 4). These values are not high for marine sediments but are typical of siliceous mud in the Bransfield strait area (De Master et al., 1987; Fabrés et al., 2000). The mean biogenic opal content was higher in G-2 and A-3 (22.92 and 21.66\%) than in G-1 and A-6 (16.73 and 13.2\%) (Fig. 4). The main features of TOC and opal showed an opposite trend (Fig. 4). Whereas the biogenic silica followed a decreasing trend, the TOC minimum followed an increasing trend (Fig. 4).

G-2 showed variable values in TOC and biogenic silica from the base of the core up to a minimum at $3.0 \mathrm{~m}$, and a broad peak followed by a minimum at $1.8 \mathrm{~m}$; the uppermost $1.2 \mathrm{~m}$ displayed a series of more or less symmetric cycles with a thickness of $20-30 \mathrm{~cm}$. A peak in biogenic silica, probably related to a diatom ooze layer, was observed at $365 \mathrm{~cm}$.

The mean features of G-1 are an increase in TOC and biogenic silica from the base of the core to 2.0 $\mathrm{m}$, a gradual but irregular decrease up to $1.2 \mathrm{~m}$, and then three well-defined peaks at $0.9,0.5$ and $0.3 \mathrm{~m}$.

The TOC record of A-3 showed three clear minimum values at 35,230 and $405 \mathrm{~cm}$. The lowest values of biogenic silica were seen at almost the same depths: 35,235 and $410 \mathrm{~cm}$. Whereas the biogenic silica minimum followed a decreasing trend, the TOC minimum followed an increasing trend (Fig. 4). Both variables followed the same trend in core A-6, with TOC peaks at 15 and $45 \mathrm{~cm}$. The maximum in biogenic silica is recorded at $35 \mathrm{~cm}$, separated by a minimum at $30 \mathrm{~cm}$.

The overall patterns of the organic components were well correlated and the most striking features were seen for all three components: TOC, silica and absolute abundance of diatom valves (Fig. 3 and 4). Biogenic opal contents and diatom valve abundances tended to decrease towards the core top, while TOC mainly increased upwards. 


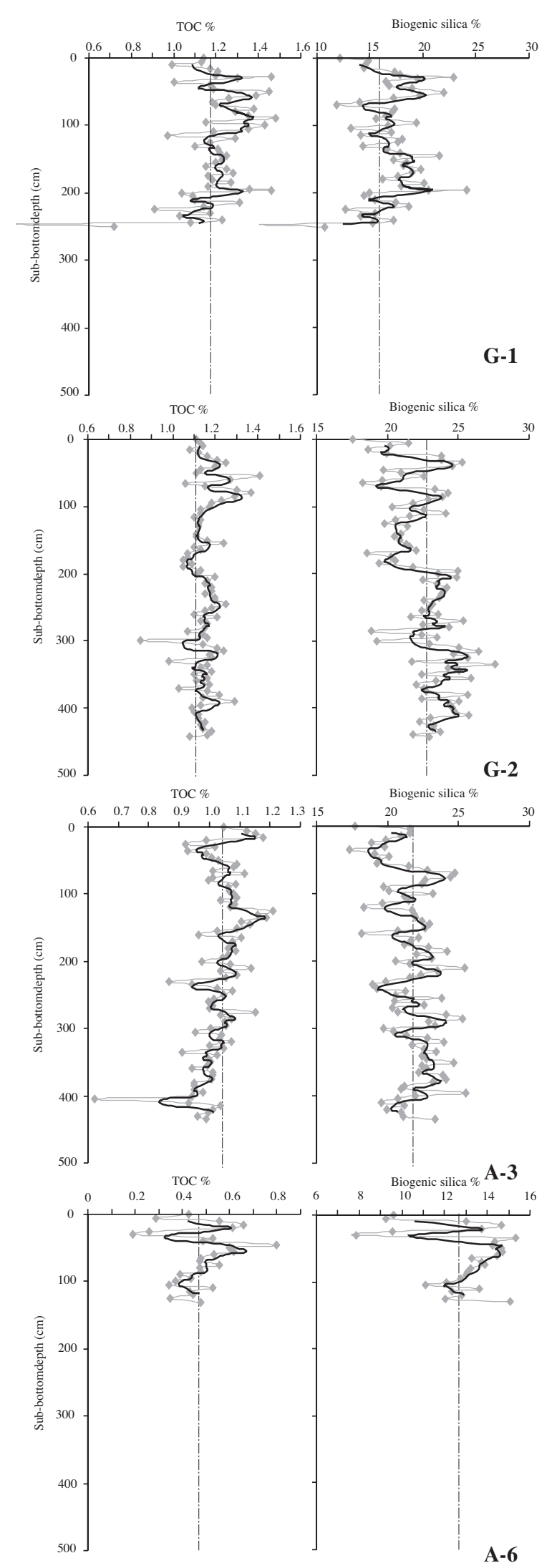

FIG. 4. - Total organic carbon and biogenic silica values obtained from G-1, G-2, A-3 and A-6. The thicker line indicates a three-point smoothing.

\section{DISCUSSION AND CONCLUSIONS}

The well-documented maxima in SITG seem to be quite closely related to the neoglacial events described for the Holocene, such as those observed by Bárcena et al. (1998, 2002). This point is addressed in depth in several papers, but was recently revised and compiled by Armand et al. (2005). The SITG is related to areas strongly influenced by sea-ice; its distribution in surface sediments is related to the winter sea-ice extension in the Weddell and Scotia Seas. Sediment traps deployed in the Bransfield Strait and Scotia Sea over a year revealed that during periods of sea-ice coverage the vertical flux of biosiliceous particles decreases significantly, while maximum values of SITG are reached during and after ice retreat (Abelmann and Gersonde, 1991). Thus, we consider that maximum values of SITG in the cores studied here may be related to a higher extension of the sea-ice, both spatially and seasonally. Furthermore, higher numbers of SITG are related to low values for Chaetoceros RS, indicating a reduced inter-annual diatom production. Thus, we consider that SITG can be used as a tracer of colder atmospheric conditions involving sea-ice advances and greater sea-ice coverage (Fig. 5). Crespin et al. (2004) used the temperature anomalies recorded in the EPICA Dome C Antarctic ice-core with F. curta in order to establish absolute chronology. Warmer inter-neoglacial periods are characterised by increases in Chaetoceros RS and decreases in SITG. Warmer temperatures and shorter sea-ice coverage periods would have been re-established in the Bransfield Basin during interneoglacial stages and the palaeoceanographic regime might have been similar to that observed today.

The abundance patterns of Chaetoceros RS agree with the high productivity values reported for the Bransfield Strait waters (Varela et al., 2002). In general, the record of high concentrations of Chaetoceros RS have been interpreted as indicating very high primary productivity, and this notion is supported by experimental and field data (Leventer et al., 1996). Sedimentologically, a massive sedimentation of Chaetoceros RS may have had a determinant effect on the high accumulation rates of biogenic silica in Antarctic sediments (Bareille et al., 1991). As derived from our data, it seems reasonable to speculate that during the last 3000 years surface productivity in the Bransfield Basin would have been higher than today (Fig. 6). A similar pattern in 


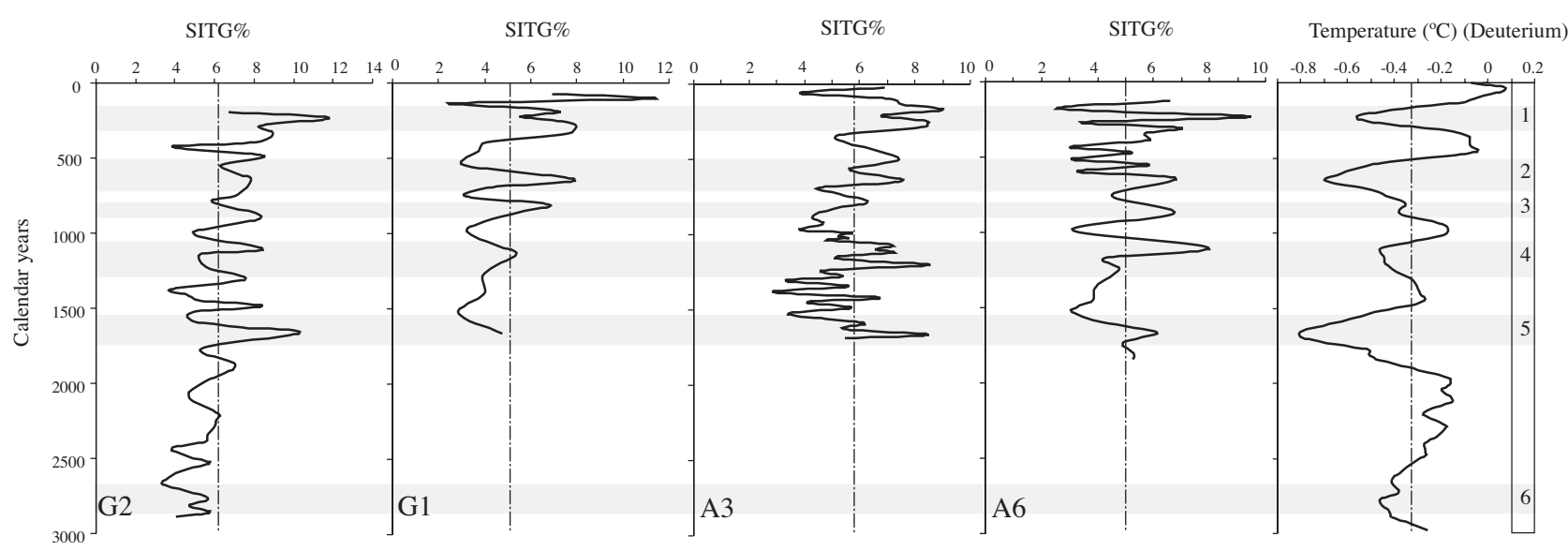

FIG. 5. - Tentative correlation between abundance variations in sea-ice taxa in all studied cores with air temperature estimations based on Deuterium content in Vostok ice-core (Petit et al., 2000).

Chaetoceros RS abundance has been observed by Leventer et al. (1996), who reported a reduction in primary siliceous productivity from three thousand years ago to today. The inferred reduction in palaeoproductivity towards the present, together with a progressive increase in SITG, seems to indicate a cooling trend (Fig. 5, 6).

Additionally, the abundance of Chaetoceros RS along the cores runs nearly parallel to the biogenic silica content, indicating a reduction in palaeoproductivity (Fig. 6). Nevertheless, TOC tends to increase towards the present. In general, TOC decays towards the top of neoglacial periods (Fig. 6), where sea-surface palaeoproductivity is expected to have been minimum. The differences in trend between Chaetoceros RS abundance and TOC contents could be explained in terms of organic matter preservation and/or in terms of the re-suspension of sediments from the continental shelf into the Bransfield Basin, as discussed in depth by Fabrés et al. (2000). As reported by Bárcena et al. (1998, 2002), higher TOC contents during cold periods could be a response to preservation rather than to annual production. Several authors have proposed that a high planktonic cell density occurs close to receding ice edges as a result of sea-ice melting and increased upper water stratification (Leventer et al., 1996). This large amount of biogenic material will flocculate and descend rapidly as aggregates to the sea floor, preventing organic matter dissolution.

Broecker and Peng (1989) consider that during cold periods the nutrient content of Antarctic surface waters could have been similar to or even higher than today. Because the extent of nutrient utilisation is larger, the $\mathrm{O}_{2}$ content of deep Antarctic waters would have been two times lower (Broecker and
Peng, 1989). If the scenario proposed by those authors is true, oxidation of the organic matter would have been lower. During neoglacial events, a similar situation would have occurred over a short time: a large amount of biogenic particles produced and precipitated during sea-ice melting would have preserved the organic matter on the sea floor. Although during warmer episodes surface productivity is higher for the entire season, the settling of biogenic particles might have been less concentrated and hence more susceptible to oxidation.

\section{Palaeoceonographic and palaeoclimatic changes}

Changes in abundance of the OWG may be related to oceanographic changes, and in particular to the entry of cold waters from the western Weddell Sea and/or from the Bellingshausen Sea-ACC into the Bransfield Strait. Thus, variations in abundance of the OWG could be used to trace surface water currents and delineate oceanographic changes in the Bransfield Strait area.

A relative increase in SITG is observed during the first stages of the neoglacial events (Fig. 5). The beginning of these episodes may have been characterised by colder temperatures. Sea-ice coverage in the Bransfield Strait may have taken place over longer periods, and induced a higher production of SITG but, as widely discussed in Bárcena et al. (1998), seasonality in the Bransfield Strait would not have been different from today. Following SITG, the OWG increased (Fig. 7). Changes in OWG abundance could be explained as being a result of oceanographic changes in the vicinity of the Weddel Sea and the Bellingshausen Sea. During the first colder steps of these neoglacial events, larg- 

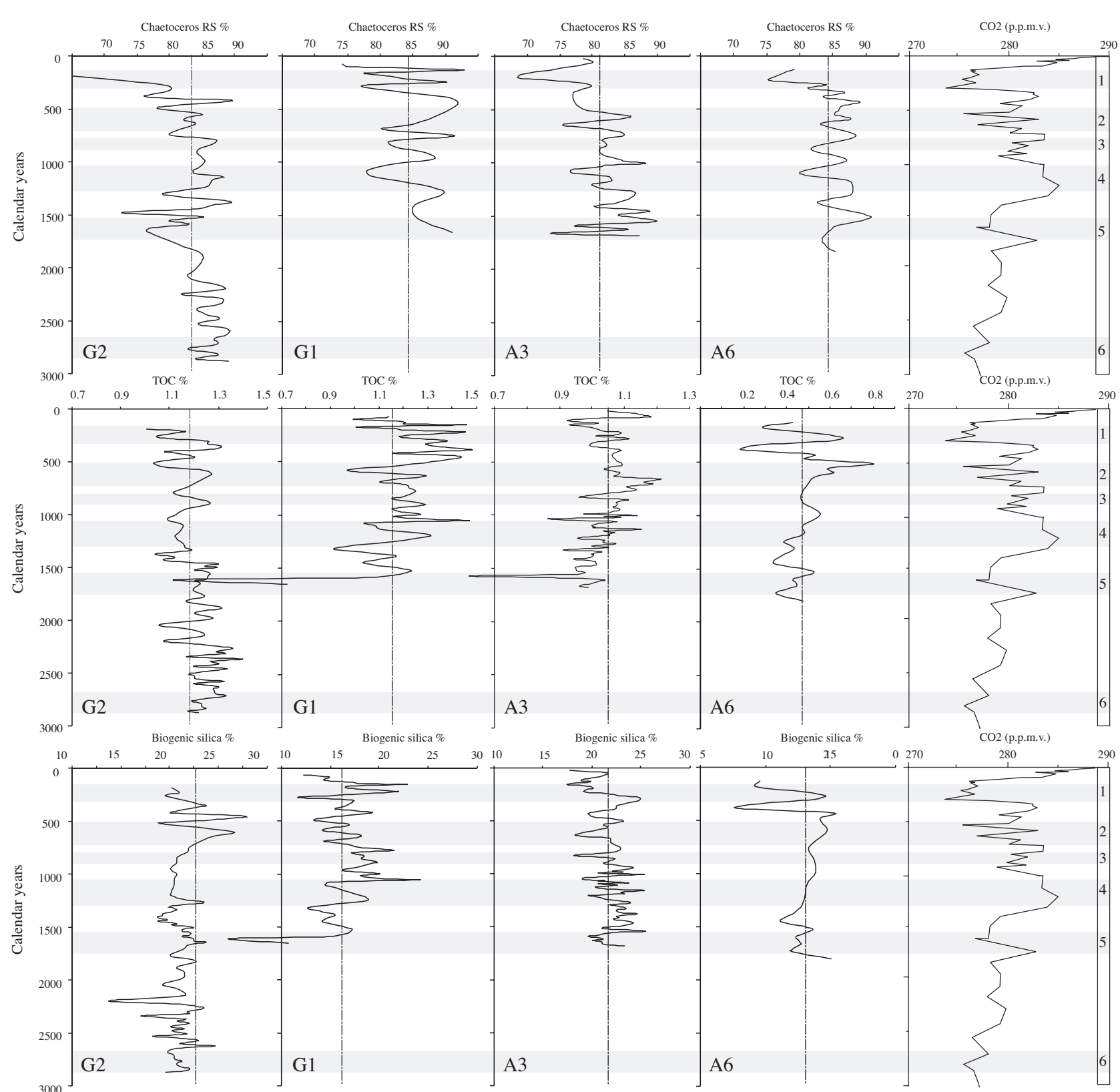

FIG. 6. - Chaetoceros RS, TOC and Silica content in cores G-1, G-2, A-3 and A-6 and their relationships to Holocene neoglacial episodes. The neoglacial events recognised have been labelled with numbers (1 to 6) after Bárcena et al. (1998). Comparison of sedimentological data with the $\mathrm{CO}_{2}$ curve produced by Indermühle et al. (1999) for the last three millennia in Taylor Dome (Antarctica). Minimum $\mathrm{CO}_{2}$ atmospheric values are related to the cold neoglacial events and to minima in TOC, biogenic silica, and Chaetoceros RS.

er areas of the Weddell and Bellingshausen Seas would have been sea-ice covered, remaining in this state for longer during the summers. Thus, a winterrestricted Bransfield Strait or Weddell and Bellingshausen Seas communication is possible, such communication possibly remaining during summers. Additionally, these larger sea-ice covered areas would have prevented the development of the OWG (since this group needs open water areas to dwell in), so the incoming amount of these taxa into the Bransfield Strait would have been severely reduced. A climatic improvement would have followed this colder time. The extension of sea-ice in the Bransfield Strait may have remained for a shorter time than before, so the abundance of SITG would have been reduced. In the surrounding primary surface water sources, sea-ice would have retreated during the summers, and the OWG would have been able to dwell in the area. Summer Bransfield Strait communications would have been re-established for longer, so a higher amount of the OWG would have entered the Bransfield Strait. 


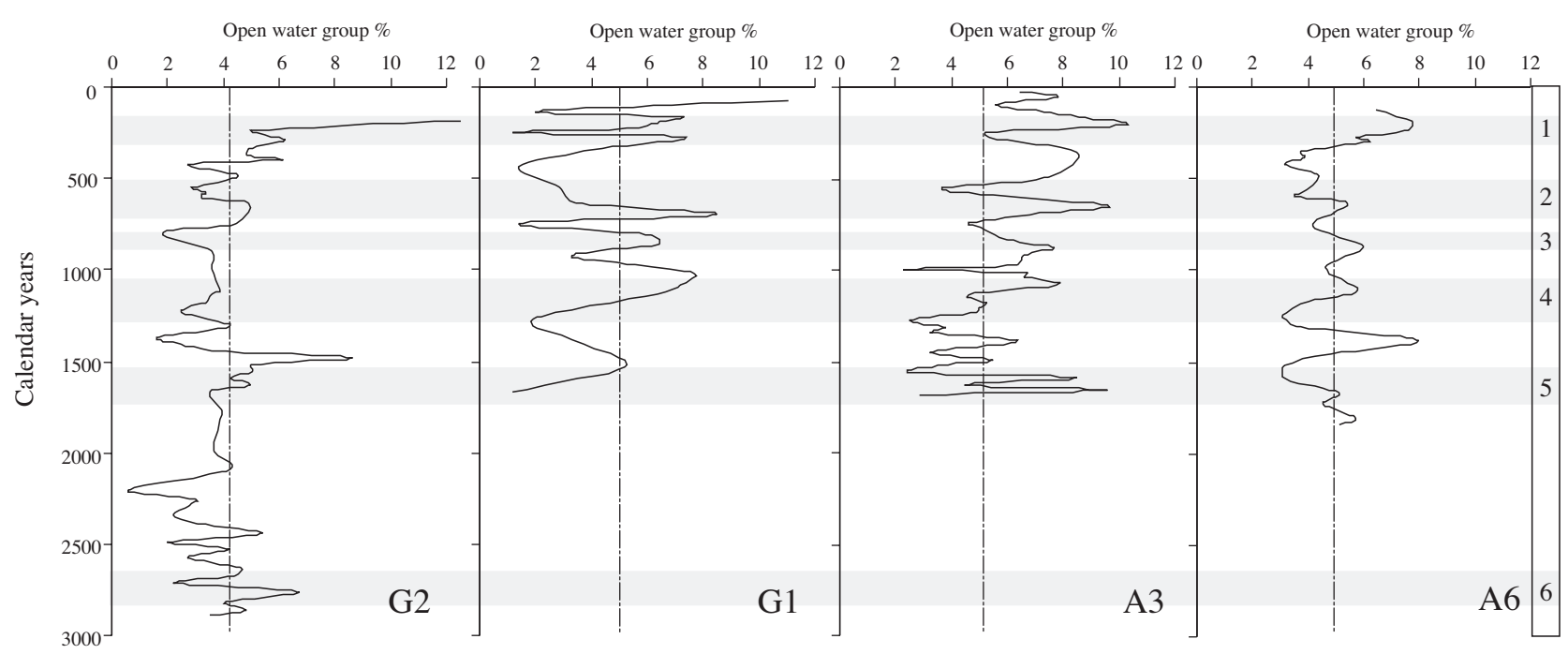

FIG. 7. - Variations in relative abundance of Open Water Group (OWG) - T. antarctica/T. scotia group and F. Kerguelensis - in all studied cores related to the neoglacial events as indicative of surface water interchange between Bransfield Strait and Weddel and Bellingshausen Seas.

\section{Bransfield Strait palaeoproductivity as related to atmospheric $\mathrm{CO}_{2}$}

Atmospheric $\mathrm{pCO}_{2}$ partial pressure $\left(\mathrm{pCO}_{2}\right)$ is an important factor in the Earth's climatic system, inducing changes in global climate and ice volumes. Atmospheric $\mathrm{CO}_{2}$ concentrations are in dynamical equilibrium with surface oceanic waters, controlled by the amount of dissolved inorganic carbon, alkalinity, temperature and surface ocean salinity. Its fluctuations are largely controlled by changes in terrestrial biomass activity, marine phytoplanktonic efficiency, biogeochemical cycles of $\mathrm{CO}_{3} \mathrm{Ca}$ and organic matter, and physical processes such as warming of the seasurface or entry of melting waters. Thus, a temperature change of the sea surface water of $1 \mathrm{mC}$ was responsible for a change in $\mathrm{pCO}_{2}$ at the sea surface of $4.2 \%$, which corresponds in the atmosphere to a change of similar magnitude (Bacastow, 1996). Nevertheless, as reported by Indermühle et al. (1999), sea surface temperature is an important mechanism but not the only one. The exchange of $\mathrm{CO}_{2}$ between the atmosphere and ocean reservoirs depends strongly upon the phototrophic productivity in oceanic upwelling regions (Sarnthein et al., 1987). Additionally, variations in the efficiency of marine phytoplankton as regards nutrient uptake could provide a link between high-latitude insolation and $\mathrm{CO}_{2}$. The highest efficiency of the marine biological pump could be reached if all the nutrients in surface waters were used by biota, drawing carbon from the atmosphere to the deep ocean and lowering the level of atmospheric $\mathrm{CO}_{2}$ (Broecker, 1981). However,
Aristegui et al. (1996) (as well as other authors) consider that at least in coastal Antarctic waters phytoplankton respiratory processes could be responsible for the loss of almost 50\% of the carbon fixed by photosynthesis. Moreover, the air breathing of top predators as well as microbial respiration may return high amounts of photosynthetically fixed carbon to the atmosphere, leading the Antarctic ecosystem to be inefficient as a carbon trap.

The ice core data suggest that $\mathrm{CO}_{2}$ levels rose significantly during warmings in the past. Indermühle et al. (1999) record atmospheric $\mathrm{CO}_{2}$ contents along the Holocene using air bubbles trapped in an ice core from the Taylor Dome (Antarctica). Numerous data point to an enhanced palaeoproductivity during glacial periods (Sarnthein et al., 1987). However, there is also evidence of low palaeoproductivity during glacial periods in areas such as the North Atlantic (Villanueva, 1996). Broecker and Peng (1989) have proposed that decreases in $\mathrm{CO}_{2}$ occurring during glacial times are a consequence of an increase in the alkalinity of Antarctic surface waters, and that this change is not only due to biologic pump efficiency but is also a natural consequence of the glacial decease of the Atlantic conveyor.

As revealed by the data obtained in this study (TOC, biogenic silica content and the Chaetoceros $\mathrm{RS}$ ), and comparing our data to the $\mathrm{CO}_{2}$ curve described by Indermühle et al. (1999) for the three millennia at the Taylor Dome (Fig. 6), reductions in atmospheric $\mathrm{CO}_{2}$ concentrations occurring during neoglacial events are seen to be related to low val- 

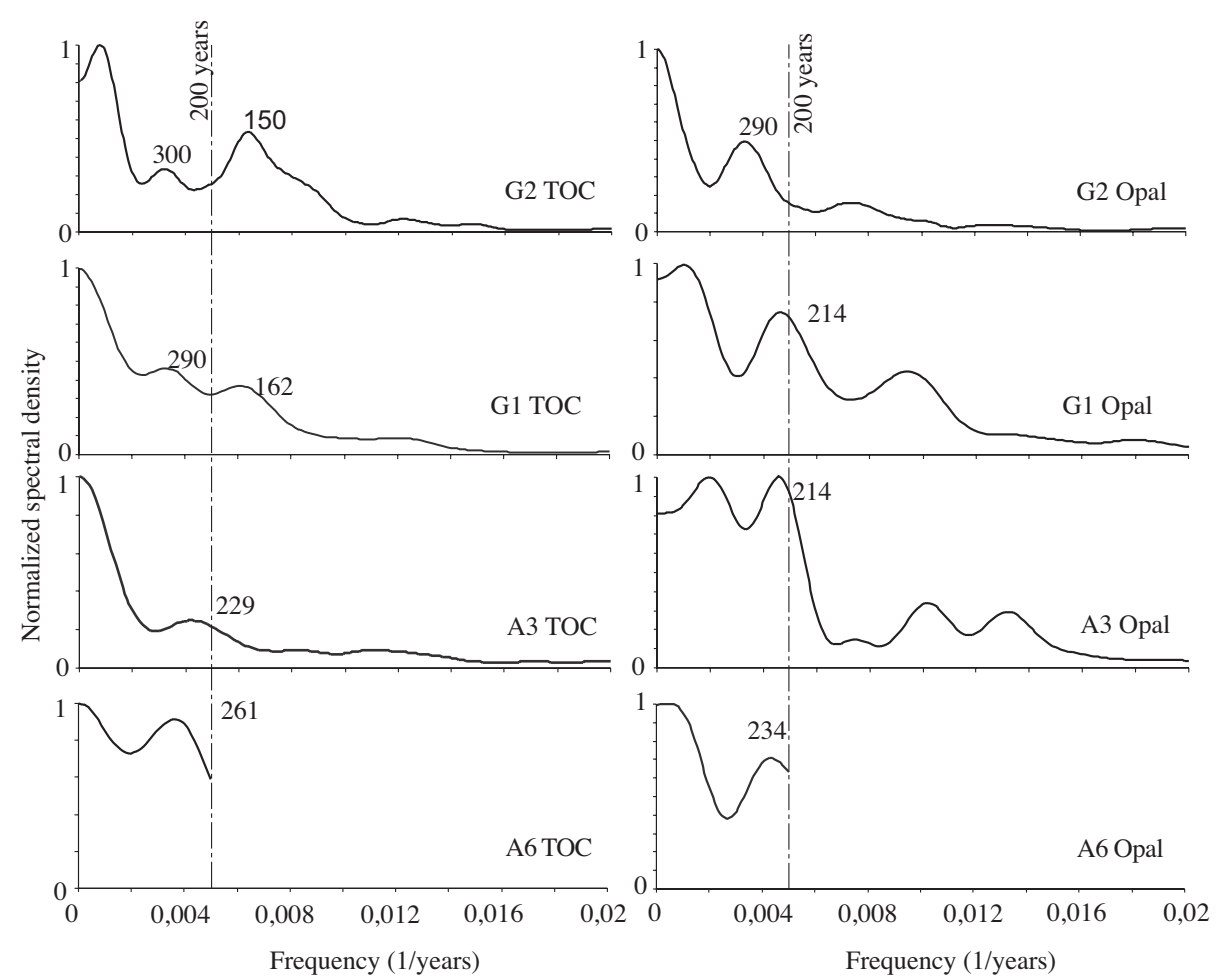

FIG. 8. - Spectral analysis of Biogenic silica content and TOC content calculated for all cores studied here. The signal has a statistically significant $\left(80 \%\right.$ level) concentration of variance in $\mathrm{a} \approx 200 \mathrm{yr}$ periodicity. The $\mathrm{x}$-axis shows frequency (years ${ }^{-1}$ ). The $\mathrm{y}$-axis shows the normalised spectral density. Blackman-Tuckey spectral analysis routines were done according to Analyses series 1.1 routines (Paillard et al., 1996).

ues in TOC, biogenic silica, diatoms and Chaetoceros RS, but no clear common pattern can be described for all the cores through time. Thus, from a global point of view, glacial periods and enhanced palaeoproductivity in upwelling regions may govern the drawdown of total $\mathrm{CO}_{2}$ by photosynthesis (Sarnthein et al., 1987). Nevertheless, for specific areas such as the Bransfield Strait, diatom communities do not play a significant role in the global $\mathrm{CO}_{2}$ cycle.

\section{Evaluation of the cyclicity record}

The world-wide occurrence of neoglacial events has meant that a primary astronomical forcing has been invoked to account for climate changes. The assumption of a constant sedimentation rate between each age tie-point and application of Blackman-Tuckey spectral analysis routines (Analyses series 1.1, Paillard et al., 1996) to different records (TOC and biogenic silica) result in a period of 200 to 300 years, using a Barllett Window type, a confidence interval of $80 \%$, and a band width of 0.002 (Fig. 8). Cross spectral analyses of the TOC and biogenic silica content demonstrate their spectral density coherence at the 80 and $90 \%$ levels, respectively, in the 200-year band. Such periodicity could be related to the effect of the 200-yr sun-spot activity cycle on the oceanic system. Little is known about solar influence on these restricted oceanic areas from the Antarctic Continent, but the observed variations in planktonic communities, organic matter and biogenic silica within the same time range as solar cycles do suggest a possible influence.

\section{ACKNOWLEDGEMENTS}

The authors would like to thank Dr. M.A. Bassetti for her valuable comments and suggestions. J. Roncero is thanked for technical assistance.

Funding for this work was generously provided by the Spanish Ministry of Science and Technology for the Ramón y Cajal Research contract 13749957M, and the projects REN2003-09622 and CGL2004-23341-E.

\section{REFERENCES}

Abelmann, A. and R. Gersonde. - 1991. Biosiliceous particle flux in the Southern Ocean. Mar. Chem., 35: 503-536.

Amos A.F. - 1987. RACER: Physical oceanography of the western 
Bransfield Strait Antarct. J. US., 22: 137-140.

Aristegui, J., M.F. Montero, S. Ballesteros, G. Basterretxea and K. van Lenning. - 1996. Planktonic primary production and microbial respiration measured by ${ }^{14} \mathrm{C}$ assimilation and dissolved oxygen changes in coastal waters of the Antarctic Peninsula during austral summer: implications for carbon flux studies. Mar. Ecol. Prog. Ser., 132: 191-201.

Armand, L.K.T, X. Crosta, O. Romero, J.J. Pichon. - 2005. The biogeography of major diatom taxa in Southern Ocean sediments: 1. Sea ice related species. Palaeogeogr. Palaeocl. Palaeoecol., 223: 93-126.

Bacastow, R. B. - 1996. The effect of temperature change of the warm surface waters of the oceans on atmospheric $\mathrm{CO}_{2}$. Global Biogeochem. Cy., 10: 319-333.

Bárcena, M.A. and F. Abrantes. - 1998. Evidence of a high-productivity area off the coast of Málaga from studies of diatoms in surface sediments. Mar. Micropaleontol., 35: 91-103.

Bárcena, M.A., R. Gersonde, S. Ledesma, J. Fabrés, A.M. Calafat, M. Canals, F.J. Sierro, and J.A. Flores. - 1998. Record of Holocene glacial oscillations in the Bransfield Basin as revealed by siliceous microfossil assemblages. Antarct. Sci. 10(3): 269-285.

Bárcena, M.A., E. Isla, A. Plaza, J.A. Flores, F.J. Sierro, P. Masqué, J.A. Sánchez-Cabeza, and A. Palanques. - 2002. Bioaccumulation record and its relation with paleoclimatic evolution in the western Bransfield Strait. Deep-Sea Res. II, 49(45): $935-950$.

Bareille, G., M. Labracherie, L. Labeyrie, J.J. Pichon and J.L. Turon. - 1991. Biogenic silica accumulation rate during the Holocene in the southeastern Indian Ocean. Mar. Chemis., 35: 537-551.

Basterrechea, G. and J. Aristegui. - 1999. Phytoplankton biomass and productionduring late austral spring (1991) and summer (1993) in the Bransfield Strait. Polar Biol., 21: 11-22.

Broecker, W.S. - 1981. Glacial to interglacial changes in ocean and atmosphere chemistry. In: A. Berger (ed.), Climatic variations and Variability: Facts and Theories, pp. 111-121. Redil Publishing Company.

Broecker, W.S. and T.H. Peng. - 1989. The cause of the glacial to interglacial atmospheric $\mathrm{CO}_{2}$ Change: A polar alkalinity hypothesis. Global Biogeochem. Cy., 3(3): 215-239.

Crespin, J., X. Crosta, V. Masson-Delmonte, A. Leventer. - 2004. Evolution of Holocene reservoir ages off Adelie Land, East Antarctica. ICP VIII, Program and Abstracts, Biarritz, 144.

Domack, E.W. - 2001. Holocene record from the Antarctic Peninsula: 200 to 1800 year oscillations. GSA Annual Meeting, November 5-8.

Domack, E.W. and P.A. Mayewski. - 1999. Bi-polar ocean linkages: evidence from late Holocene Antarctic Marine and Greenland ice-core records. Holocene 9 2): 237-241.

Ercilla, G., J. Baraza, B. Alonso, and M. Canals. - 1997. Recent geological processes in the Central Bransfield Basin (Western Antartic Peninsula). In: M.S. Stoker, D. Evans and A. Cramp (eds.), Geological Processes on Continental Margins: Sedimentation, Mass-Wasting and Stability, pp. 205-216. Geol. Soc. London, Sp. Publ.

Fabrés, J., A.M. Calafat, M. Canals, M. A. Bárcena, and J. A. Flores. - 2000. Bransfield Basin fine grained sediments: Late Holocene sedimentary processes and oceanographic and climatic conditions. Holocene, 10(9): 703-718.

Gersonde, R. and Wefer G. - 1987. Sedimentation of biogenic siliceous particles in Antarctic waters from the Atlantic sector. Mar. Micropaleontol., 11: 311-332.

Gordon, A L. and W.D. Nowlin. - 1987. The basin waters of the Bransfield Strait. J. Phys. Oceanogr. 8: 258-264.

Harden, S.L., D.J. DeMaster, and C.A. Nittrouer. - 1992.
Developing sediment geochronologies for high-latitude continental shelf deposits: a radiochemical approach. Mar. Geol., 103: 69-97.

Indermühle, A., T.F. Stocker, F. Joss, H. Fisher, H.J. Smith, M. Wahlen, B.M. Deck, D. Mastroianni, J. Tschumi, T.M. Blunier, R. Meyer, and B. Stauffer - 1999. Holocene carbon-cycle dynamics based on $\mathrm{CO}_{2}$ trapped in ice at Taylor Dome (Antarctica). Nature, 398: 121-126.

Leventer, A., E. Domack, S.E. Ishman, S. Brachfeld, C.E. McClennen, and P. Manley. - 1996. Productivity cycles of 200300 years in the Antarctic Peninsula region: Understanding linkages among the sun, atmosphere, oceans, se ice, and biota. Geol. Soc. Am. Bull., 108(12): 1626-1644.

Mortlock, R. A. and P. N. Froelich. - 1989. A simple method for the rapid determination of biogenic opal in pelagic marine sediments. Deep-Sea Res., 36(9): 1415-1426.

N.O.C. - 1985. Naval Oceanography Command Detachment, Asheville. Sea Ice Climatic Atlas, 1: Antarctic.

Paillard, D., L. Labeyrie, and P. Yiou. - 1996. Macintosh program performs timeseries analyses. Eos Trans, AGU, 77: 379.

Palanques, A., E. Isla, P. Puig, J.A. Sánchez-Cabeza, and P. Masqué. - 2002. Annual evolution of downward particle fluxes in the Western Bransfield Strait (Antarctica) during the FRUELA project. Deep-Sea Res. II, 49(4-5): 903-920.

Petit, J.R., D. Raynaud, C. Lorius, J. Joudel, G. Delaygue, N.I. Barkov, and V.M. Kotlyakov. - 2000. Historical isotopic temperature record from the Vostok ice core. In: Trends: A Compendium of Data on Global Change. Carbon Dioxide Information Analysis Center, Oak Ridge National Laboratory, J.S. Department of Energy, Oak Ridge, Tenn., J.S.A.

Sarnthein, M., K. Winn, and R. Zahn. - 1987. Paleoproductivity of oceanic upwelling and the effect on atmospheric $\mathrm{CO}_{2}$ and climatic changes during deglaciation times. In: W.H. Berger and L.D. Labeyrie (eds.), Abrupt Climate Change, Proceedings of the NATO/NSF A.R.W. Symposium at Biviers/Grenoble 1985, pp. 311-337.

Schrader H.J. and R. Gersonde. - 1978. Diatoms and silicoflagellates. In: W.J. Zachariasse et al. (eds.), Micropaleontological counting methods andtechniques- an exercise on an eight metres section of the lower Pliocene of Capo Rossello, Sicily. Utrecht Micropal. Bull., 17: 129-176.

Stuiver, M., G.H. Denton, T.J. Hughes, J.L. Fastook. - 1981. History of the marine ice sheet in west Antarctica during the last glaciation: A working hypothesis. In: G. Denton and T. Hughes (eds.), The Last Great Ice Sheets, pp. 319-436. John Wiley and Sons, New York.

Varela, M. E. Fernández and P. Serret - 2002. Side-fractionated phytoplankton biomass and primary production in the Gerlache and South Bransfield Straits (Antarctic Peninsula) in the austral summer 95-96. Deep-Sea Res. II, 49: 749-768.

Villanueva, J. - 1996. Estudi de les variacions climàtiques y oceanogràiques a l'Atlantic Nord durant els últims 3000000 anys mitjancant l'anàlisi de marcadors moleculars. Ph.D. thesis, Univ. Ramon Llull.

Wefer, G., G. Fischer, D.K. Fütterer and R. Gersonde. - 1988. Seasonal particle flux in the Bransfield Strait, Antarctica. DeepSea Res., 35(6): 891-898.

Zielinski, J. and R. Gersonde. - 1997. Diatom distribution in Southern Ocean surface sediments (Atlantic sector): Implications for palaeoenvironmental reconstructions. Palaeogeogr. Palaeocl. Palaeoecol., 129: 213-250.

Received September 15, 2005. Accepted September 5, 2006.

Scient. ed.: M.P. Olivar.

Published online October 23, 2006. 
